\title{
Diagnostic potential of epiphytic bryophytes in forest vegetation classification
}

\author{
Ilya Kucherov ${ }^{1 *}$, Galina Grishutkina ${ }^{2}$, Victoria Teleganova ${ }^{3}$, and Alexey Potemkin ${ }^{1}$ \\ ${ }^{1}$ Komarov Botanical Institute RAS, 197376 St. Petersburg, Russia \\ 2"Wildland Mordovia" Federal State Institution, 430005 Saransk, Republic of Mordovia, Russia \\ ${ }^{3}$ Ugra National Park, 248007 Kaluga, Russia
}

\begin{abstract}
The article reveals that epiphytic and epixylic bryophytes could be successfully used as differentials in classification of forest communities together with vascular plants and epigeic cryptogams, the fact proved for broadleaved forests in European Russia.
\end{abstract}

\section{Introduction, materials and methods}

Epiphytic and epixylic species of bryophytes and lichens are likely to serve as differentials not only of their synusiae [1] but also at the level of forest communities where they grow forming integrated diagnostic groups together with vascular plant and epigeic bryophytes. This publication is aimed at tracing the role of the epiphytic/epixylic bryophytes in floristic differentiation of broadleaved forests where the role of the epiphytic bryosynusia is maximal.

The study is based upon 112 relevés of broadleaved forests made in the Mordovian and Kaluzhskie Zaseki Nature Reserves (European Russia) by I. Kucherov in 2015-2016. Projective cover $(\%)$ of each species was estimated for each community layer together with soil texture and topographical location in plots not less than $400 \mathrm{~m}^{2}$ in area. Epigeic, epiphytic (growing up to $0.6-1 \mathrm{~m}$ high from the trunk base) and epixylic bryophytes, totally not less than 600 multispecies moss and over 100 hepatic specimens were sampled for further studies by bryologists. Species composition of samples was identified by G. Grishutkina for the Mordovian Reserve and by V. Teleganova (mosses) and A. Potemkin (hepatics) for the Kaluzhskie Zaseki Reserve. The classification of vegetation was accomplished using the combined dominant-floristic approach which implies distinguishing the syntaxa according to dominants with further adjustment of their volume by determinant groups of ecologically close species. Epiphytes and epixyles were considered together with vasculars and epigeic bryophytes. The differentiation is represented in Tables 1 and 2 for each of the reserves separately; only determinants and prominent constants are shown in the tables.

\section{Results and discussion}

In the Kaluzhskie Zaseki Reserve $\left(54^{\circ} \mathrm{N}, 36^{\circ} \mathrm{E}\right)$ (see Table 1 ), oak (Quercus robur) forests dominated by Carex pilosa in the field layer, developed on loamy sands of hilly watershed

\footnotetext{
* Corresponding author: atragene@ mail.ru
} 
terrain and upper parts of slopes, are adjoint to those of the Matteuccia struthiopteris and Galeobdolon luteum variant of the Aegopodium podagraria- and Allium ursinum-dominated oak forests on even placor surfaces with heavy soil texture by a determinant group led by ash Fraxinus excelsior. Epiphytes and epixyles included in this group are Cladonia coniocraea, Sciuro-hypnum populeum, and rare Pylaisia polyantha. No one of these species is associated with ash directly. The group of non-inundated oak forest syntaxa also includes the variant of Lunaria rediviva and Mercurialis perennis of the Aegopodium-dominated forests in watershed depressions and bottom parts of slopes. The set of determinants of this group is headed by Acer platanoides in the tree layer and A. campestre in the undergrowth. Nemoral mesophytic herbs Galium odoratum and Dentaria bulbifera also join the group together with several nemoral (Neckera pennata, Serpoleskea subtilis) and multizonal (Pseudoleskeella nervosa) basiphilous epiphytic moss species. The ecologically and chorologically similar Anomodon longifolius, A. viticulosus, and Leucodon sciuroides occur only in the Aegopodium-dominated oak forests of the two mentioned variants in line with Ulmus glabra and Acer campestre in the tree layer. Maximal abundance of old trees of A.platanoides inhabited by the Anomodon species is observed in the same communities. Both the noninundated and the inundated (floodplain) Aegopodium-dominated oak forests, the latter codominated by Impatiens noli-tangere and Filipendula ulmaria s.l. in their field layer, are united by a set of the multizonal (Urtica dioica), boreal-nemoral (Matteuccia struthiopteris, Stellaria nemorum, Impatiens noli-tangere), and nemoral (Allium ursinum, Lamium maculatum) mesophytes and hygromesophytes. Homalia trichomanoides, also a hygromesophyte, is a representative of basiphilous epiphytic mosses in this set. This species is absent in the less moist Carex pilosa-dominated oak forests.

A system of the uneven-aged Quaternary terraces is well-expressed in the Mordovian Reserve area $\left(55^{\circ} \mathrm{N}, 43^{\circ} \mathrm{E}\right.$ ) (see Table 2). The first of them is a living floodplain of the Moksha River with a soil cover of heavy or medium loam. Oak groves with a species-poor field layer dominated by Urtica dioica and Glechoma hederacea are typical for this terrace. Their determinants are Ulmus laevis in the tree and the regrowth layers, Rubus caesius, also several boreal-nemoral hygromesophytic (Filipendula ulmaria s.l., Scrophularia nodosa) and mesohygrophytic (Solanum dulcamara) herbs. The multizonal epiphytic Leskea polycarpa, common in the floodplain, also joins the determinant group. The second and the third accumulative terraces of the Valdai (Würm) age are composed of deep sand underlain by limestone and covered by linden (Tilia cordata) forests with Corylus avellana and the field layer dominated by either Aegopodium podagraria (the typical variant), or Carex pilosa, often with the admixture of Quercus robur in the tree layer. Nitrophilous mesophytes with maxima of their abundance and cover on the first terrace (Urtica dioica, Glechoma hederacea, Alliaria petiolata) adjoin the oak groves of the latter with Aegopodium-dominated linden forests of the upper two terraces in contrast to Carex pilosa-dominated ones. Cardamine impatiens, Adoxa moschatellina, Matteuccia struthiopteris are also included into this group together with the epiphytic Homalia trichomanoides and Pylaisia polyantha. The first of these moss species mainly occurs on the lower two terraces whereas the last one inhabits all three. The residual fourth terrace of the Dnieper (Riss) age, composed of sand underlain by moraine loam, is covered by hemiboreal pine (Pinus sylvestris) forests with Tilia cordata and Corylus avellana in combination with Carex pilosa-dominated linden forests. Such boreal and boreal-nemoral mesotrophic mesophytes as Betula pendula, Carex digitata, Maianthemum bifolium, and Rubus saxatilis are common only in the forests of these types. The epiphytes which are in the same group are close to the vascular species mentioned in their ecology and zonal distribution. These are Plagiothecium laetum s.l. (the companion of Picea abies) and Pleurozium schreberi growing as an epiphyte only on this terrace. 
Table 1. Floristic differentiation of broadleaved forests in Kaluzhskie Zaseki Nature Reserve

\begin{tabular}{|c|c|c|c|c|c|}
\hline \multirow{3}{*}{ Species } & \multirow{3}{*}{ Layer } & \multicolumn{4}{|c|}{ Syntaxa } \\
\hline & & \multirow{2}{*}{ I } & \multicolumn{3}{|c|}{ II } \\
\hline & & & $\mathrm{A}$ & $\mathrm{B}$ & $\mathrm{C}$ \\
\hline Tilia cordata & $\mathrm{b}_{2}$ & $76^{4}$ & $27^{+}$ & \multirow{2}{*}{$\begin{array}{l}25^{+} \\
38^{1}\end{array}$} & $11^{+}$ \\
\hline Carex pilosa & $\mathrm{c}$ & $100^{33}$ & $14^{2}$ & & $11^{1}$ \\
\hline Lathyrus vernus & $\mathrm{c}$ & $82^{1}$ & $14^{+}$ & \multirow{3}{*}{$13^{+}$} & $11^{+}$ \\
\hline Dicranum scoparium & $\mathrm{Z}$ & $47^{+}$ & $14^{+}$ & & $22^{+}$ \\
\hline Fraxinus excelsior & $a_{1}$ & $53^{6}$ & $50^{8}$ & & \\
\hline Acer platanoides & $a_{2}$ & $82^{8}$ & $\mathbf{5 5}^{11}$ & $38^{8}$ & $33^{5}$ \\
\hline Tilia cordata & $a_{2}$ & $71^{12}$ & $41^{3}$ & $25^{7}$ & $33^{4}$ \\
\hline Paris quadrifolia & $\mathrm{c}$ & $65^{+}$ & $73^{+}$ & $25^{+}$ & $33^{+}$ \\
\hline Cladonia coniocraea & $\mathrm{z}$ & $76^{+}$ & $45^{+}$ & \multirow[t]{3}{*}{$25^{+}$} & \multirow[t]{3}{*}{$22^{+}$} \\
\hline Sciuro-hypпum populeum & $\mathrm{z}$ & $18^{+}$ & $27^{+}$ & & \\
\hline Pylaisia polyantha & $\mathrm{z}$ & $6^{+}$ & $14^{+}$ & & \\
\hline Acer platanoides & $a_{1}$ & $53^{5}$ & $68^{13}$ & $\mathbf{8 8}^{21}$ & \multirow[t]{4}{*}{$33^{8}$} \\
\hline A. campestre & $a_{3}$ & $29^{1}$ & $41^{3}$ & $38^{1}$ & \\
\hline A. campestre & $b_{2}$ & $53^{+}$ & $73^{1}$ & $88^{2}$ & \\
\hline A. platanoides & $b_{3}$ & $88^{2}$ & $50^{+}$ & $63^{+}$ & \\
\hline Galium odoratum & $\mathrm{c}$ & $59^{2}$ & $73^{5}$ & $75^{3}$ & \multirow{2}{*}{$33^{1}$} \\
\hline Dentaria bulbifera & $\mathrm{c}$ & $53^{1}$ & $5^{+}$ & $38^{+}$ & \\
\hline Brachythecium salebrosum & $\mathrm{Z}$ & $59^{+}$ & $73^{+}$ & $50^{+}$ & \multirow[t]{4}{*}{$22^{+}$} \\
\hline Serpoleskea subtilis & $\mathrm{z}$ & $35^{+}$ & $64^{+}$ & $38^{+}$ & \\
\hline Neckera pennata & $\mathrm{z}$ & $29^{+}$ & $5^{+}$ & $38^{+}$ & \\
\hline Pseudoleskeella nervosa & $\mathrm{Z}$ & $6^{+}$ & $18^{+}$ & $13^{+}$ & \\
\hline Ulmus glabra & $a_{1}$ & $18^{1}$ & $45^{5}$ & $63^{7}$ & \multirow[t]{2}{*}{$11^{8}$} \\
\hline Acer campestre & $a_{2}$ & \multirow{3}{*}{$29^{+}$} & $32^{3}$ & $50^{4}$ & \\
\hline Anomodon longifolius & $\mathrm{z}$ & & $64^{+}$ & $88^{+}$ & \multirow[t]{3}{*}{$33^{+}$} \\
\hline A. viticulosus & $\mathrm{z}$ & & $14^{+}$ & $38^{+}$ & \\
\hline Leucodon sciuroides & $\mathrm{z}$ & \multirow{3}{*}{$29^{2}$} & $14^{+}$ & $38^{+}$ & \\
\hline Ulmus glabra & $b_{1}$ & & $68^{7}$ & $63^{4}$ & $56^{6}$ \\
\hline Urtica dioica & $\mathrm{c}$ & & $91^{3}$ & $88^{3}$ & $89^{3}$ \\
\hline Allium ursinum & $\mathrm{c}$ & $18^{+}$ & $50^{12}$ & $100^{11}$ & $89^{10}$ \\
\hline Impatiens noli-tangere & $\mathrm{c}$ & 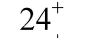 & $73^{1}$ & $50^{4}$ & $67^{21}$ \\
\hline Lamium maculatum & $\mathrm{c}$ & $24^{+}$ & $45^{1}$ & $75^{1}$ & $67^{1}$ \\
\hline Stellaria nemorum & $\mathrm{c}$ & $12^{+}$ & $45^{1}$ & $63^{3}$ & $67^{3}$ \\
\hline Matteuccia struthiopteris & $\mathrm{c}$ & & $64^{12}$ & $38^{1}$ & $67^{4}$ \\
\hline Homalia trichomanoides & $\mathrm{z}$ & $29^{+}$ & $82^{+}$ & $88^{+}$ & $67^{+}$ \\
\hline Lunaria rediviva & $\mathrm{c}$ & \multirow{4}{*}{$6^{+}$} & \multirow{4}{*}{$\begin{array}{c}5^{+} \\
27^{+} \\
9^{1}\end{array}$} & $\mathbf{8 8}^{19}$ & $33^{1}$ \\
\hline Athyrium filix-femina & $\mathrm{c}$ & & & $38^{1}$ & $56^{3}$ \\
\hline Filipendula ulmaria s.l. & $\mathrm{c}$ & & & $50^{+}$ & $89^{5}$ \\
\hline Oxyrrhynchium hians & d & & & $13^{1}$ & $44^{5}$ \\
\hline Quercus robur & $a_{1}$ & $94^{25}$ & $95^{28}$ & $75^{14}$ & $78^{17}$ \\
\hline Aegopodium podagraria & $\mathrm{c}$ & $94^{5}$ & $100^{17}$ & $100^{17}$ & $100^{14}$ \\
\hline Galeobdolon luteum & $\mathrm{c}$ & $100^{6}$ & $100^{13}$ & $88^{8}$ & $78^{6}$ \\
\hline Mercurialis perennis & $\mathrm{c}$ & $76^{4}$ & $77^{8}$ & $\mathbf{8 8}^{15}$ & $89^{6}$ \\
\hline Plagiomnium cuspidatum & z & $82^{+}$ & $91^{+}$ & $88^{+}$ & $78^{+}$ \\
\hline Callicladium haldanianum & $\mathrm{z}$ & $65^{+}$ & $68^{+}$ & $63^{+}$ & $89^{+}$ \\
\hline Dicranum montanum & $\mathrm{z}$ & $82^{+}$ & $64^{+}$ & $50^{+}$ & $56^{+}$ \\
\hline Number of relevés & & 17 & 22 & 8 & 9 \\
\hline
\end{tabular}

Notes. Syntaxa: I - Quercetum pilosae-caricosum, II - Q. ursini-allioso-aegopodiosum with variants: A of Matteuccia struthiopteris, B - of Lunaria rediviva, C - of Filipendula ulmaria. Layers: $\mathrm{a}_{1}, \mathrm{a}_{2}, \mathrm{a}_{3}-$ dominant and subordinate tree layers; $b$ - regrowth and shrubs: $b_{1}-$ tall (> 3-4 m high), $b_{2}-$ medium, $b_{3}-$ low ( $\leq 1 \mathrm{~m}$ high); c - field layer; $\mathrm{d}$ - ground layer; $\mathrm{z}$ - epiphytes. Constancy $(\%)$ and average cover (\%) (in superscripts) are given for species. Diagnostic groups are marked with bold margins, $\mathrm{z}$ species also with shading. Species within the groups are sorted first by layer, then by descending occurrence in the whole table relevé set. Cover and constancy values are shown in bold for dominants. Average cover under $0.5 \%$ is given as "+". 
The Aegopodium-dominated lime forests of the Mercurialis perennis variant with the abundant Acer platanoides in the 2nd canopy layer occur on heavy soil in depressions of all the three non-inundated terraces, also at the upland fringe of the Satis River (the Moksha River tributary). Such nemoral species as Lunaria rediviva and Brachythecium rutabulum, the latter growing on trunk basements, are typical for these forests only. Amongst the species with more extended zonal ranges, Chiloscyphus profundus is also found only in the forests of this variant. But it occurs on all the terraces except the lowest one, and Brachythecium rutabulum inhabits only the upper two. Forests of this variant have a common determinant group with floodplain oak groves: it comprises Padus avium, Oxyrrhynchium hians, and the epiphytic Anomodon attenuatus, already known for its affiliation to floodplain habitats. This species almost exclusively occurs on the lower two terraces as well as Homalia trichomanoides, Leskea polycarpa and rare Myrinia pulvinata. All the non-inundated broadleaved-forest types are united by the presence of Picea abies and Pinus sylvestris as admixtures in the tree layer, also by Acer platanoides in the undergrowth and many nemoral mesophytic herbs like Aegopodium podagraria, Pulmonaria obscura, Mercurialis perennis, and Asarum europaeum. The same group of determinants also includes both Carex pilosa and Lamium maculatum together with Galium odoratum, also such boreal-nemoral herbs as Lathyrus vernus, Milium effusum, Dryopteris carthusiana, and Stellaria holostea. The epiphytic and epixylic bryophytes and lichens of this group are mainly represented by multizonal species with extensive ranges (Brachythecium salebrosum, Brachytheciastrum velutinum, Stereodon pallescens, Cladonia coniocraea), but the nemoral basiphilous Anomodon longifolius, the companion of Acer platanoides, is distributed in the same way in this area.

It follows from the above that all the recognized broadleaved-forest syntaxa are subject to distinct floristic differentiation with the help of not only vascular but also epiphytic bryophyte species under ecologically contrasting habitat conditions. The integrated diagnostic groups including both vasculars and epiphytic bryophytes are being formed due to the action of ecological factors which uniformly influence both groups of species [2]. The ecological and phytocoenotical association of these species presumably originates due to the climatic and especially the microclimatic factors. The air humidity and temperature ranges near the ground may be of the main importance among the latter [3]. The edaphic factors do not influence the association of vasculars and epiphytic bryophytes within the integrated diagnostic groups directly, but their indirect influence may be essential. The increased soil moisture should facilitate an air moisture increase, important for the effectiveness of bryophyte reproduction. Most nemoral species of epiphytic mosses also grow on tree bark with a basic reaction [4], typical for the broadleaved tree species. Many of the latter, in their turn, are dependent on soil with increased fertility and facilitate the genesis of such soil themselves by their litter.

The detailed results of this study have been recently published in Russian [5]. The work of I. Kucherov and A. Potemkin has been carried out in accordance with the current official planning tasks of the Komarov Botanical Institute RAS, projects 121032500047-1 "Vegetation of European Russia and Northern Asia: Diversity, dynamics, and principles of organization" and 121021600184-6 "Flora and taxonomy of algae, lichens and bryophytes of Russia and florologically significant regions of the World", respectively. 
Table 2. Floristic differentiation of broadleaved forests in Mordovian Nature Reserve

\begin{tabular}{|c|c|c|c|c|c|}
\hline \multirow[b]{2}{*}{ Species } & \multirow[b]{2}{*}{ Layer } & \multicolumn{4}{|c|}{ Syntaxa } \\
\hline & & 1 & & 3 \\
\hline Betula pendula & $a_{1}$ & $68^{4}$ & $36^{1}$ & $30^{3}$ & $15^{1}$ \\
\hline Carex digitata & $\mathrm{c}$ & $42^{+}$ & $14^{+}$ & $10^{+}$ & \\
\hline Rubus saxatilis & $\mathrm{c}$ & $42^{1}$ & $7^{+}$ & $10^{+}$ & \\
\hline Maianthemum bifolium & $\mathrm{c}$ & $37^{+}$ & $7^{+}$ & & \\
\hline $\begin{array}{l}\text { Plagiothecium laetum s.l. } \\
\text { Pleurozium schreberi }\end{array}$ & $\begin{array}{l}\mathrm{Z} \\
\mathrm{z}\end{array}$ & $\begin{array}{l}21^{+} \\
26^{+}\end{array}$ & $7^{+}$ & & \\
\hline Picea abies & $a_{1}$ & $37^{2}$ & $64^{2}$ & $70^{3}$ & \\
\hline Pinus sylvestris & $a_{1}$ & $53^{6}$ & $43^{3}$ & $40^{6}$ & \\
\hline Acer platanoides & $a_{2}$ & $63^{11}$ & $50^{4}$ & $70^{23}$ & $23^{8}$ \\
\hline A. platanoides & $b_{1}$ & $\begin{array}{l}79^{15} \\
05^{7}\end{array}$ & $\begin{array}{r}86^{14} \\
100^{39}\end{array}$ & $\begin{array}{r}80^{14} \\
100^{15}\end{array}$ & $15^{1}$ \\
\hline & $\begin{array}{l}\mathrm{c} \\
\mathrm{c}\end{array}$ & $\begin{array}{c}95^{7} \\
100^{3}\end{array}$ & $\begin{array}{l}100^{39} \\
100^{2}\end{array}$ & $\begin{array}{c}\mathbf{1 0 0}_{50^{1}}^{15} \\
-\end{array}$ & $\begin{array}{l}23^{4} \\
15^{+}\end{array}$ \\
\hline $\begin{array}{l}\text { Lathyrus vernus } \\
\text { Pulmonaria obscura }\end{array}$ & $\begin{array}{l}\mathrm{c} \\
\mathrm{c}\end{array}$ & $63^{1}$ & $\begin{array}{l}100 \\
100^{4}\end{array}$ & $90^{2}$ & $23^{+}$ \\
\hline Mercurialis perennis & $\mathrm{c}$ & $58^{3}$ & $100^{8}$ & $100^{22}$ & $8^{+}$ \\
\hline Lamium maculatum & $\mathrm{c}$ & $58^{1}$ & $50^{1}$ & $80^{4}$ & $15^{+}$ \\
\hline Milium effusum & $\mathrm{c}$ & $42^{+}$ & $57^{4}$ & $50^{+}$ & $15^{2}$ \\
\hline Dryopteris carthusiana & $\mathrm{c}$ & $53^{+}$ & $21_{2}^{+}$ & $50^{+}$ & $8^{+}$ \\
\hline Galium odoratum & $\mathrm{c}$ & $37^{2}$ & $29^{2}$ & $30^{3}$ & $8^{+}$ \\
\hline Asarum europaeum & $\mathrm{c}$ & $100^{4}$ & $93^{4}$ & $80^{3}$ & \\
\hline Carex pilosa & $\mathrm{c}$ & $100^{43}$ & $79^{8}$ & $50^{3}$ & \\
\hline Stellaria holostea & $\mathrm{c}$ & $95^{2}$ & $50^{+}$ & $60^{1}$ & \\
\hline Brachythecium salebrosum & $\mathrm{z}$ & 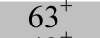 & $57^{+}$ & $40^{+}$ & $15^{+}$ \\
\hline Stereodon pallescens & $\mathrm{z}$ & 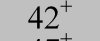 & $36^{+}$ & $60^{+}$ & $15^{+}$ \\
\hline Brachytheciastrum velutinum & $\mathrm{z}$ & $47^{+}$ & $43^{+}$ & $20^{+}$ & $15^{+}$ \\
\hline Anomodon longifolius & $\mathrm{z}$ & $21^{+}$ & $14^{+}$ & $30^{+}$ & \\
\hline Cladonia coniocraea & $\mathrm{z}$ & $21^{+}$ & $14^{+}$ & $20^{+}$ & \\
\hline Urtica dioica & $\mathrm{c}$ & $16^{+}$ & $71^{2}$ & $60^{3}$ & $100^{25}$ \\
\hline Glechoma hederacea & $\mathrm{c}$ & $21^{+}$ & $50^{1}$ & $30^{+}$ & $100^{33}$ \\
\hline Adoxa moschatellina & $\mathrm{c}$ & & $36^{+}$ & $30^{+}$ & $15^{+}$ \\
\hline Cardamine impatiens & $\mathrm{c}$ & & $21^{+}$ & $20^{+}$ & $31_{1}^{+}$ \\
\hline Matteuccia struthiopteris & $\mathrm{c}$ & & $7^{+}$ & $10^{1}$ & $23^{1}$ \\
\hline Homalia trichomanoides & $\mathrm{z}$ & $5^{+}$ & $36^{+}$ & $30^{+}$ & $46^{+}$ \\
\hline Pylaisia polyantha & $\mathrm{z}$ & $5^{+}$ & $29^{+}$ & $20^{+}$ & $23^{+}$ \\
\hline Lunaria rediviva & $\mathrm{c}$ & & & $40^{17}$ & \\
\hline Chiloscyphus profundus & $\mathrm{z}$ & $11^{+}$ & $7^{+}$ & $40^{+}$ & \\
\hline Brachythecium rutabulum & $\mathrm{z}$ & $11^{+}$ & & $50^{+}$ & $8^{+}$ \\
\hline Padus avium & $b_{2}$ & $16^{+}$ & $14^{+}$ & $40^{+}$ & $46^{3}$ \\
\hline Oxyrrhynchium hians & $\mathrm{d}$ & & & $10^{5}$ & $8^{+}$ \\
\hline Anomodon attenuatus & $\mathrm{z}$ & $5^{+}$ & & $10^{+}$ & $23^{+}$ \\
\hline Ulmus laevis & $\mathrm{a}_{2}$ & & $7^{+}$ & & $54^{5}$ \\
\hline Rubus caesius & $b_{3}$ & & & & $46^{5}$ \\
\hline Scrophularia nodosa & $\mathrm{c}$ & $5^{+}$ & $29^{+}$ & $20^{+}$ & $77^{+}$ \\
\hline Filipendula ulmaria s.l. & $\mathrm{c}$ & & & & $54^{1}$ \\
\hline Solanum dulcamara & $\mathrm{c}$ & & & & $38^{+}$ \\
\hline Leskea polycarpa & $\mathrm{z}$ & $11^{+}$ & $21^{+}$ & $10^{+}$ & $85^{+}$ \\
\hline Tilia cordata & $a_{1}$ & $\mathbf{6 3}^{26}$ & $\mathbf{9 3}^{42}$ & $90^{40}$ & $62^{21}$ \\
\hline Quercus robur & $a_{1}$ & $32^{4}$ & $43^{9}$ & $20^{3}$ & $77^{30}$ \\
\hline Corylus avellana & $b_{1}$ & $26^{2}$ & $21^{5}$ & $20^{1}$ & $31^{3}$ \\
\hline Plagiomnium cuspidatum & $\mathrm{z}$ & $89^{+}$ & $71^{+}$ & $60^{+}$ & $38^{+}$ \\
\hline Serpoleskea subtilis & $\mathrm{z}$ & $58^{+}$ & $64^{+}$ & $50^{+}$ & $31^{+}$ \\
\hline Platygyrium repens & $\mathrm{z}$ & $32^{+}$ & $57^{+}$ & $20^{+}$ & $77^{+}$ \\
\hline Pseudoleskeella nervosa & $\mathrm{z}$ & $42^{+}$ & $57^{+}$ & $40^{+}$ & $23^{+}$ \\
\hline Number of relevés & & 19 & 14 & 10 & 13 \\
\hline
\end{tabular}

Notes. Syntaxa: I - Tilietum pilosae-caricosum, II - T. aegopodiosum with variants: A - typica, B - of Mercurialis perennis; III - Quercetum glechomoso-urticosum. For other notes, see Table 1. 


\section{References}

1. R. Marstaller, Haussknechtia, 13 (2006)

2. A. Notov, Wulfenia, 17 (2010)

3. P. Stoutjesdijk, J. Barkman, Microclimate, vegetation and fauna (Uppsala, Opulus, 1992)

4. H. Ellenberg, H. Weber, R. Düll, W. Wirth, W. Werner, D. Paulißen, Scripta Geobot., 18 (1992)

5. I. Kucherov, G. Grishutkina, V. Teleganova, A. Potemkin, TvSU Bulletin, Biology and Ecology, 1 (61) (2021) 